\title{
PEMFC Fault Diagnosis, Modeling, and Mitigation
}

\author{
Abraham Gebregergis, Member, IEEE, Pragasen Pillay, Fellow, IEEE, and Raghunathan Rengaswamy
}

\begin{abstract}
This paper introduces fault diagnosis and separation, mitigation, and modeling of a proton exchange membrane fuel cell (PEMFC). Experimental tests of a single PEMFC were performed during this study. Flooding and drying faults were implemented to be detected from the cell voltage and impedance response of the cell. The impedance response at low frequency was used to identify the cause of the fault. The slope of the magnitude and/or the negative phase response of the cell impedance at low frequency were observed to allow separation of a fault. A cell impedance model based on resistive capacitive $(\mathrm{C}$ model) and resistive constant-phase-element (CPE model) circuits is developed. The CPE model has a better approximation of the cell impedance. However, the $\mathbf{C}$ model is easy to implement since it is well known in most simulation tools (MATLAB/Simulink or PSpice). A power electronic control is designed and tested to mitigate the faults. Pulsing the cell current at low frequency was seen to increase the cell power by $8 \%$ during drying.
\end{abstract}

Index Terms-Fault, fuel cell, modeling, proton exchange membrane fuel cell (PEMFC), simulation.

\section{INTRODUCTION}

$\mathbf{F}$ UEL CELLS are a promising energy technology with the advantages of high efficiency and low pollution for transportation and stationary applications. However, fuel cells also have challenging problems associated with its durability, lifetime, etc. For example, the carbon monoxide (CO) poisoning of the catalyst, flooding of the cell cathode side, and drying of the cell membrane are issues that deserve attention.

Many studies have been done to address $\mathrm{CO}$ poisoning of a catalyst in a fuel cell [1]-[6]. Research shows a decrease in the cell voltage performance of the fuel cell with an increase in the content of $\mathrm{CO}$ in the fuel supplied to the fuel cell. The poisoning problem is more severe when operating at low temperature like a proton exchange membrane fuel cell (PEMFC) as compared to a phosphor acid fuel cell. Other studies have discovered a means to improve CO tolerance of a fuel cell [2]-[6]. An alloy catalyst platinum-ruthenium $(\mathrm{Pt}-\mathrm{Ru})$ was used instead of

Paper ICPSD-09-43, presented at the 2008 Industry Applications Society Annual Meeting Edmonton, AB, Canada October 5-9 and approved for publication in the IEEE TRANSACTIONS ON INDUSTRY APPLICATIONS by the Energy Systems Committee of the IEEE Industry Applications Society. Manuscript submitted for review November 15, 2008 and released for publication June 3, 2009. Current version published January 20, 2010.

A. Gebregergis is with the Innovation Center, Delphi Steering, Saginaw, Saginaw, MI 48601 USA (e-mail: abraham.g.gebregergis@ delphi.com).

P. Pillay is with the Department of Electrical and Computer Engineering, Concordia University, Montreal, QC H4G 2M1, Canada (e-mail: pillay@ encs.concordia.ca).

R. Rengaswamy is with the Department of Chemical Engineering, Texas Tech University, Lubbock, TX 79409-3121 USA (e-mail: raghu.rengasamy@ ttu.edu).

Color versions of one or more of the figures in this paper are available online at http://ieeexplore.ieee.org.

Digital Object Identifier 10.1109/TIA.2009.2036677 platinum at the anode of a PEMFC to reduce the adsorption of carbon monoxide on the active catalyst surface of Pt [2]. The reaction at the anode for uncontaminated hydrogen is

$$
\begin{aligned}
\mathrm{H}_{2}+2(\mathrm{Pt}) & \longrightarrow 2(\mathrm{Pt}-\mathrm{H}) \\
2(\mathrm{Pt}-\mathrm{H}) & \longrightarrow 2(\mathrm{Pt})+2 \mathrm{H}^{+}+2 e^{-} .
\end{aligned}
$$

However, if hydrogen is contaminated with $\mathrm{CO}$, the reaction at the anode could occur in either of the following two processes:

$$
\begin{aligned}
\mathrm{CO}+(\mathrm{Pt}) & \longrightarrow(\mathrm{Pt}=\mathrm{CO}) \\
2 \mathrm{CO}+2(\mathrm{Pt}-\mathrm{H}) & \longrightarrow 2(\mathrm{Pt}=\mathrm{CO})+\mathrm{H}_{2} .
\end{aligned}
$$

The Pt-Ru alloy catalyst is used to reduce the $\mathrm{CO}$ adsorption significantly on the Pt catalyst at the anode of a PEMFC. This allows a water-gas shift reaction to occur if the fuel is humidified before it is fed into the anode. The reactions that occur in the anode are

$$
\begin{aligned}
(\mathrm{Pt})+\mathrm{H}_{2} \mathrm{O} & \longrightarrow(\mathrm{Pt}-\mathrm{OH})+\mathrm{H}^{+}+e^{-} \\
\mathrm{Ru}+\mathrm{H}_{2} \mathrm{O} & \longrightarrow(\mathrm{Ru}-\mathrm{OH})+\mathrm{H}^{+}+e^{-} \\
(\mathrm{Pt}=\mathrm{CO})+(\mathrm{Ru}-\mathrm{OH}) & \rightarrow(\mathrm{Pt})+\mathrm{Ru}+\mathrm{CO}_{2}+\mathrm{H}^{+}+e^{-}
\end{aligned}
$$

Another approach to oxidizing the $\mathrm{CO}$ adsorbed on the catalyst surface into carbon dioxide $\left(\mathrm{CO}_{2}\right)$ is air bleeding into the anode with the fuel stream [3]. This helps to free some of the active catalyst site on the $\mathrm{Pt}$ available for hydrogen $\left(\mathrm{H}_{2}\right)$. Moreover, a thin catalyst layer was added onto the anode, where a direct oxidation of $\mathrm{CO}$ with $\mathrm{O}_{2}$ occurs, before the fuel reaches the internal catalyst layer in which $\mathrm{H}_{2}$ is oxidized [4]. Operating the cell at higher temperature could also improve the tolerance of $\mathrm{CO}$ poisoning [3], [5]. However, the dynamics of the fuel cell will be significantly affected, which limits its application for transportation. Interesting results of improved CO tolerance of a PEMFC were found when an advanced power converter system was used that draws a pulsing current [6]. A low-frequency pulsating current was drawn from the fuel cell, which drives (pushes) the fuel cell to operate at high overpotential in the $V-I$ curve. Operating the PEMFC at high overpotential allows $\mathrm{CO}$ oxidation into $\mathrm{CO}_{2}$, which frees some of the active catalyst surface of $\mathrm{Pt}$ to allow a fast electro-oxidation of $\mathrm{H}_{2}$.

Water management is crucially important for healthy operation of a PEMFC. [7]-[10] discuss monitoring a PEMFC during flooding and drying conditions using an electrochemical impedance spectroscope (EIS) and by measuring the cell resistance and pressure drop. Monitoring the liquid water content in porous electrodes by measuring the pressure drop between 
the inlet and the outlet was proposed in [7]. A combination of pressure drop at the cathode side and measuring the cell resistance is used to reliably indicate separately between drying and flooding faults [8]. [9] uses impedance response at separate frequency ranges to distinguish between flooding and drying faults. A detailed analysis of the state of health of a PEMFC using an EIS to detect and isolate is presented in [10]. This study uses a Randles cell to model the cell during both flooding and drying.

However, detection and isolation of the faults in a PEMFC operation are not enough. The act of mitigating these faults is critically important to improve the performance of the cell and have longer lifetime. This paper proposes not only detection and isolation of the fault source but also mitigating of the cell from flooding, drying, and CO poisoning faults. An EIS is used to detect and isolate the cause of the fault, and a simple boost-buck cascaded dc-dc converter is designed to mitigate the fault. Pulsating the cell current was observed to increase the cell power by $8 \%$.

\section{Flooding AND DRYing OF A PEMFC}

The membrane of the PEMFC has to be wet for normal operations. The water inside the membrane transports the protons $\left(\mathrm{H}^{+}\right)$from the anode side to the cathode side by osmosis through the membrane. Enough water in the membrane can be achieved by humidifying the incoming fuel $\left(\mathrm{H}_{2}\right)$ and air $\left(\mathrm{O}_{2}\right)$. However, any shortcomings that arise due to the imperfect humidifier sensors can lead to too much or too little water being injected into the fuel cell, which, in turn, causes flooding or drying. Prolonged operation in either of these two states decreases the output power of the fuel cell. Furthermore, this can be very harmful, or even fatal, to the fuel cell [7]. For flooding to occur, excess water has to be injected into the cell and operates at high current density. It is a slow process of liquid water accumulation inside the cathode gas diffusion layer (GDL) of the cell. During this process, the voltage drops slowly as if the current was limited by the diffusion of reactants. Eventually, water droplets are formed inside the gas channels that prevent oxygen from reaching the catalytic sites, thus rapidly reducing the cell voltage to zero. For drying to occur, too little water is injected into the cell, and it operates at a low current density. The membrane of the cell dries out, and the voltage gradually drops. Eventually, the cell dries out, and the voltage drops suddenly to zero in a similar manner to a concentration drop. Detection of flooding and drying while it is during the slow-voltage-drop stage is important as prolonged operation is extremely harmful to the fuel cell [7].

\section{EXPERIMENTAL SetuP}

All measurements were carried out on a single PEMFC fed with air and pure hydrogen. The fuel cell experimental test setup consists of a $10-\mathrm{cm}^{2}$ single cell, gas humidifiers, line heaters for the gas inlet lines, a moisture trap, a cell temperature controller, a mass flow controller for the incoming reactant gases, and a back pressure controller for the exiting gases, as shown in Fig. 1. The schematics of the cell connected to

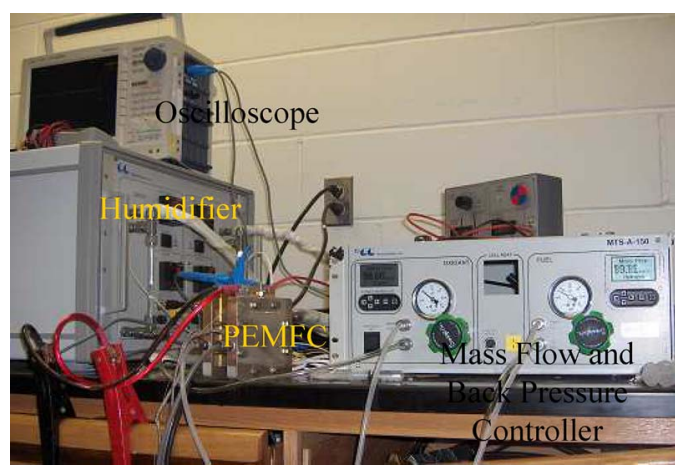

Fig. 1. Experimental test setup of the EIS of a PEMFC.

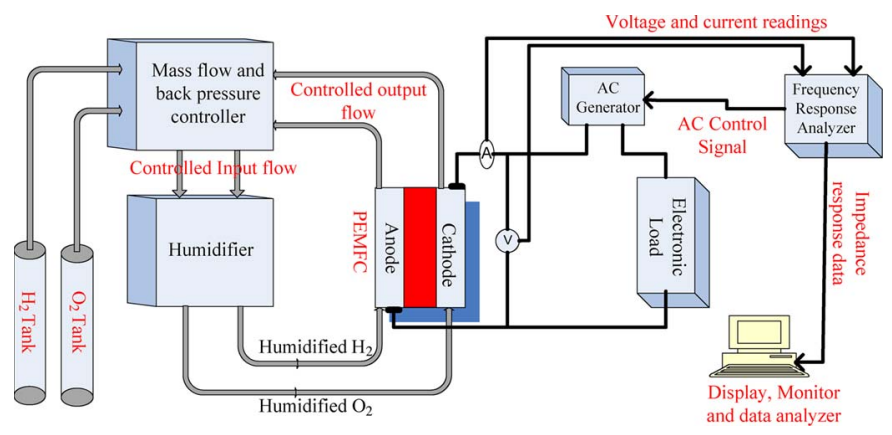

Fig. 2. Schematics of the experimental test of the PEMFC.

an electronic load and a frequency response analyzer (FRA) are shown in Fig. 2. The following parameters of the cell were maintained to ensure consistency and repeatability of the experiment for all the experiments carried out.

1) Pure oxygen $\left(\mathrm{O}_{2}\right)$ and hydrogen $\left(\mathrm{H}_{2}\right)$ flow are set at $100 \mathrm{sccm}$ during the test, and the fuel and oxidant flow back pressure is kept at $20 \mathrm{lb} / \mathrm{in}^{2}$.

2) The humidity is maintained at the desired level using the humidifier by controlling the humidifier temperature.

3) The cell current was controlled at a predetermined level, which, in this case, is $8 \mathrm{~A}$, using the electronic load. An FRA is used to collect the impedance response of the cell during the course of the test, and an oscilloscope records the voltage response in time while the cell is either drying or flooding.

\section{A. Flooding Procedure}

Initially, the cell and the humidifier temperatures are kept the same for normal operation. To create flooding in the cell, the humidifier temperature is maintained at about $40{ }^{\circ} \mathrm{C}$ or higher than the cell temperature. The cell can be operated at very high current to facilitate the flooding process. This creates a situation where there is a net water gain into the fuel cell, and the cell is eventually flooded. This process leads to a drop of the cell voltage. Finally, the fuel cell reaches a point where the voltage falls to a very low level, indicating that flooding has occurred.

\section{B. Drying Procedure}

Drying of the cell can be achieved by creating a temperature difference between the humidifier and the cell. Similar to the 


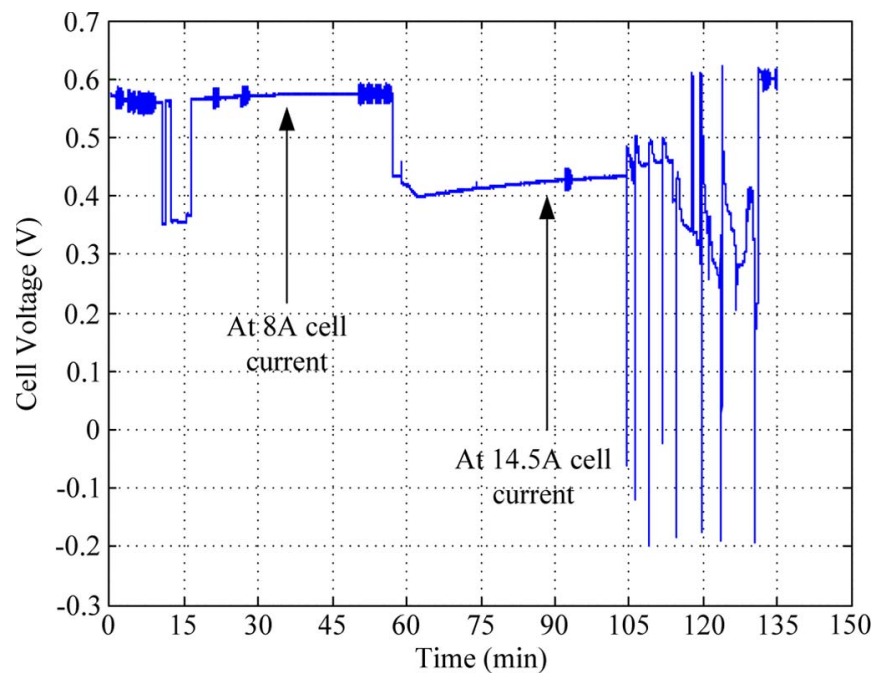

Fig. 3. Cell voltage response during flooding.

flooding process, at the beginning, the temperature difference is kept to zero for normal operation. The cell temperature is then maintained at about $40^{\circ} \mathrm{C}$ or higher than the humidifier to create drying. Operating the cell at low current will speed up the drying process. This process creates a net water loss from the fuel cell. As a result, the cell membrane starts to dry with time. Eventually, a fall in the cell voltage is seen over time. Finally, the fuel cell reaches a point where the cell voltage drops to zero and it can no longer produce current.

\section{EXPERIMENTAL RESUlts AND Discussion}

The FRA is employed to provide the forcing signal to the ac generator and collect the impedance response, as shown in Fig. 1. The amplitude of the ac signal is set to a maximum amplitude of $30 \mathrm{mV}$, which injects less than $5 \%$ ac current into the cell at the selected operating current (dc cell current). The cell current is maintained at $8 \mathrm{~A}$ during the experiment using the electronic load. The frequency sweep range of the ac signal is set from 0.1 to $15 \mathrm{kHz}$ of ten sweeps/decade. If the frequency sweep decreased below $0.1 \mathrm{~Hz}$, the data collected are very noisy and hard to analyze. The imaginary part of the impedance response will be dominated by an inductive impedance if the sweep frequency increases above $15 \mathrm{kHz}$ due to the inductance of the connecting wires.

Flooding of the cell was attempted at an 8-A operating cell current, as shown in Fig. 3. Unfortunately, complete flooding without injecting water into the cathode side of the cell was not successful. The cell current was increased to $14.5 \mathrm{~A}$ after about $3600 \mathrm{~s}$, operating at $8 \mathrm{~A}$ to force the cell to flood completely, as shown in Fig. 3. The fluctuating voltage response starting from about 6000 to $8100 \mathrm{~s}$ shows a sign of complete flooding of the cell. The cell voltage drops to zero and recovers to a higher voltage value and then slowly decreases where it finally drops again to zero. During this flooding stage, the back pressure of the unreacted exiting oxygen was seen to drop, which also indicates flooding. It was observed that recording the $V-I$ data of the cell during this complete flooding is hard since the cell recovers and continues with normal operation for a short period of time. A very low oxygen content is still diffused through

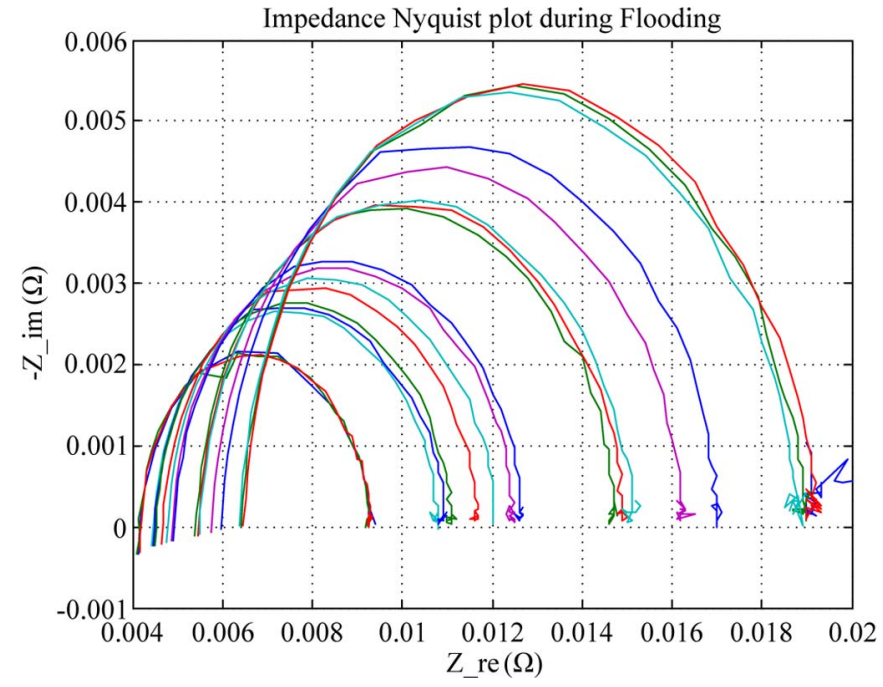

Fig. 4. Impedance response of the cell during flooding.

the cathode GDL and reaches the catalyst region generating current during this complete flooding stage. The cell resumes its normal operation once it is operated at low current densities, which increases its output power.

The impedance response of the cell during the flooding process is shown in Fig. 4. Both the real and imaginary parts of the cell impedance increase as the liquid water accumulation in the cathode side increases. However, the shape (semicircle) of the impedance response remains almost the same with the exception of increased diameter and shifting slightly to the right. The increase in the polarization resistance (bulk charge transfer resistance) in the cathode side causes the increase in the diameter of the cell impedance response. The slight shift of the semicircle to the right is due to the decrease in cell temperature, which increased the membrane resistance. An empirical formula [11] was used to calculate the cell membrane resistance as a function of the temperature and operating cell current. The result of the empirical formula and the measured resistance are almost the same. The maximum magnitude of the imaginary part of the impedance response of the cell occurs at the same frequency $630 \mathrm{~Hz}$. This implies that the transient response remains the same. Fig. 5 shows the magnitude and phase response of the cell impedance. An increase in the cell magnitude response is seen as the cell floods, but the phase response remains almost the same throughout the flooding. A negative phase shift is seen between $50-\mathrm{Hz}$ and $5-\mathrm{kHz}$ frequency ranges, which indicates almost the same transient response of the cell (settling time of $0.5 \mathrm{~ms}$ ) between the different flooding stages and the healthy cell.

Figs. 6 and 7 show the voltage response of the cell during the drying process. Complete drying of the cell was seen to occur after running for about $7800 \mathrm{~s}$ at an 8-A operating cell current, as shown in Fig. 6. The drying resulted in a slow decrease of the cell voltage from 0.58 to $0.475 \mathrm{~V}$, and finally rapidly drops from 0.45 to $0.258 \mathrm{~V}$, which indicates complete drying. The cell was also subjected to drying again after recovering to normal operation. The second drying process took less time to completely dry the cell, which is about $3600 \mathrm{~s}$, as shown in Fig. 7. The drying resulted in a reduction of $50 \%$ of the 

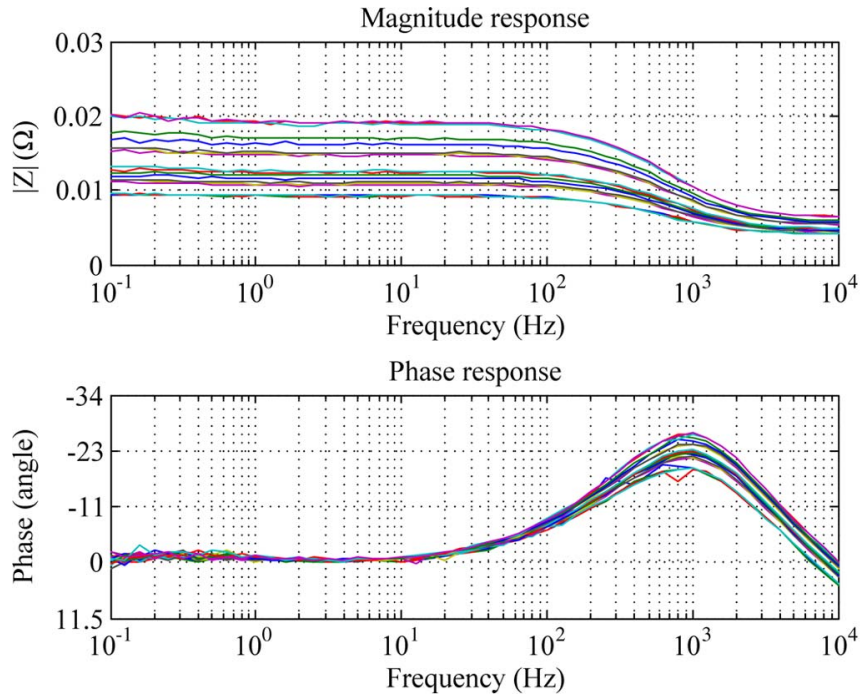

Fig. 5. Magnitude and phase responses of the cell during flooding.

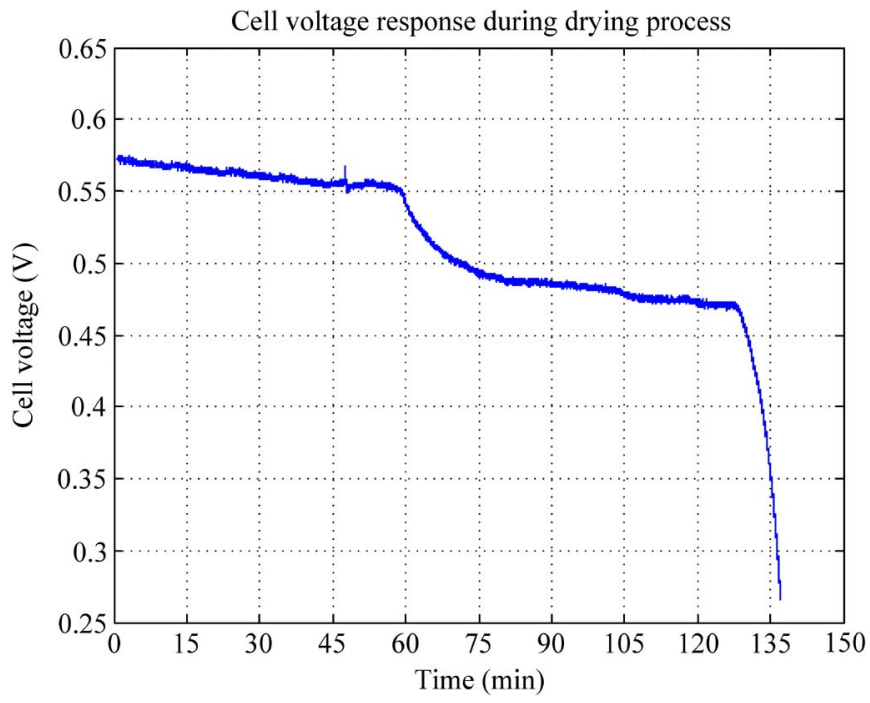

Fig. 6. Voltage response during the initial drying attempt.

maximum power output of the cell. A power and $V-I$ curve comparison of the normal and drying operation is shown in Fig. 8 with a maximum power of $4.6 \mathrm{~W}$. The actual maximum power loss is about $2.354 \mathrm{~W}$, and the voltage drop at $8 \mathrm{~A}$ is $0.308 \mathrm{~V}$.

The impedance response of the cell during the drying stages is shown in Figs. 9 and 10. Fig. 9 shows the real versus the imaginary part of the impedance response, and the magnitude and phase responses are shown in Fig. 10. The plot shows an increase in the magnitude of the real and imaginary responses and a generation of another semicircle at low frequencies. A negative slope $(\mathrm{d}|Z| / \mathrm{d} f)$ of the magnitude response plot for the low-frequency test, and a negative phase shift start to appear as the cell membrane dries, which does not occur for normal and flooding. This helps to identify the drying fault from flooding and the healthy cell. In addition, the dynamic response of the cell starts to become slower (settling time of $0.87 \mathrm{~s}$ ) than the response of the healthy cell (settling time of about $0.35 \mu \mathrm{s}$ ).

A fault in the cell operation can easily be detected by measuring the cell voltage. A drop in the cell voltage at a given

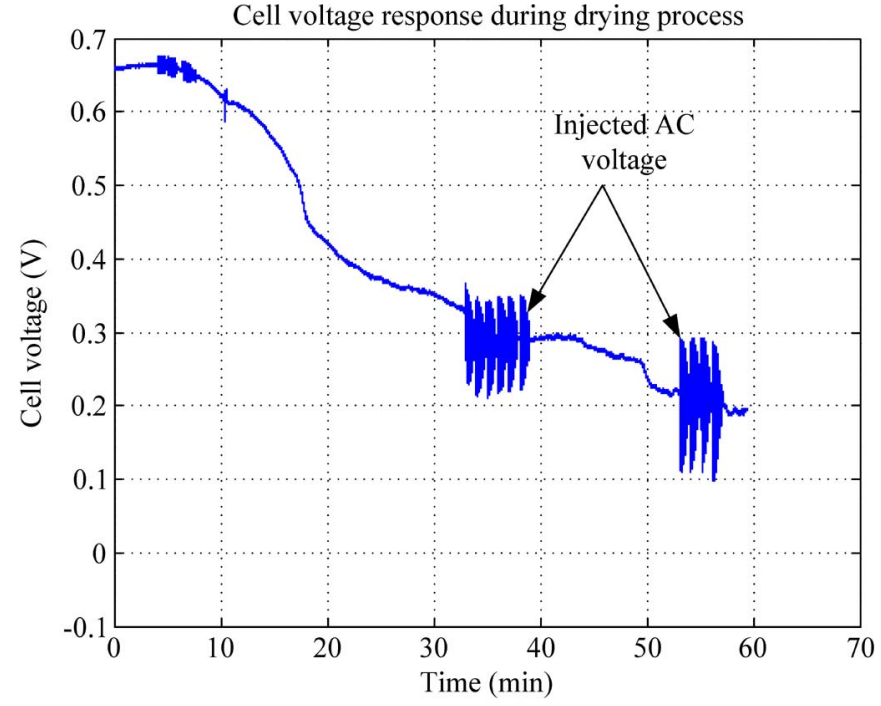

Fig. 7. Voltage response during the second drying attempt.

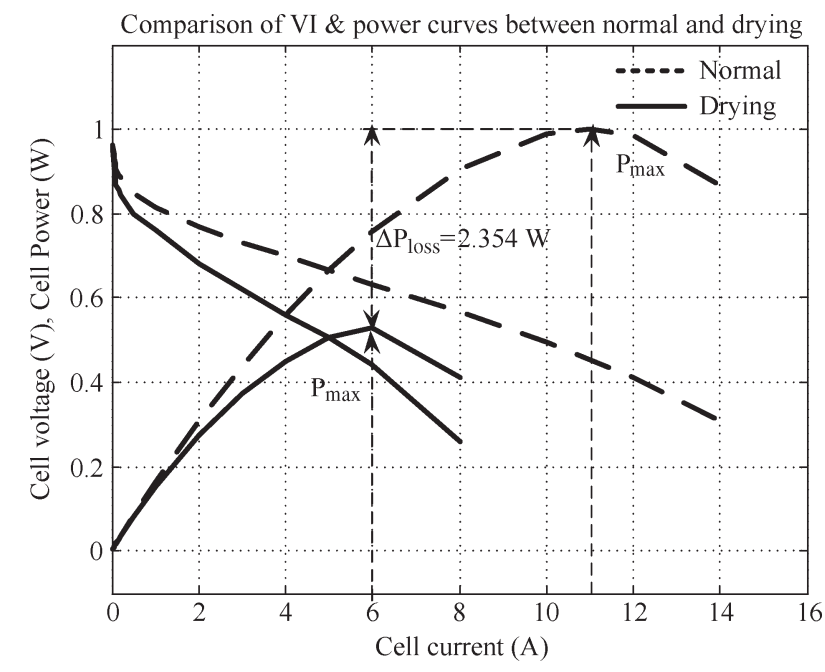

Fig. 8. Power and $V-I$ curves for a healthy and a drying cell.

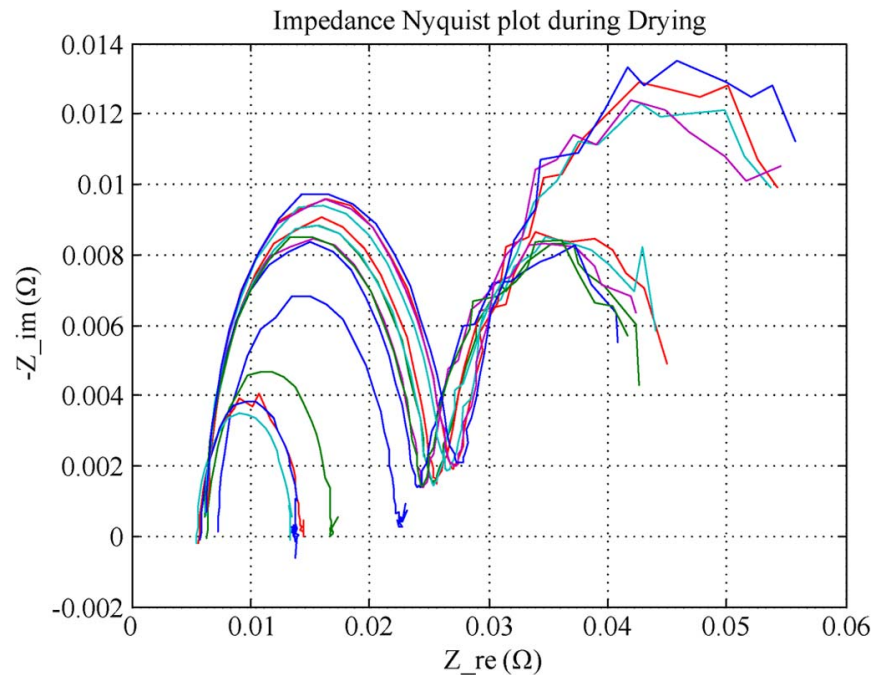

Fig. 9. Impedance response of the cell during drying.

operating current could lead to a fault occurring in the cell. Limiting the cause of the fault to either flooding or drying, the magnitude or phase response of the cell at low frequency can 

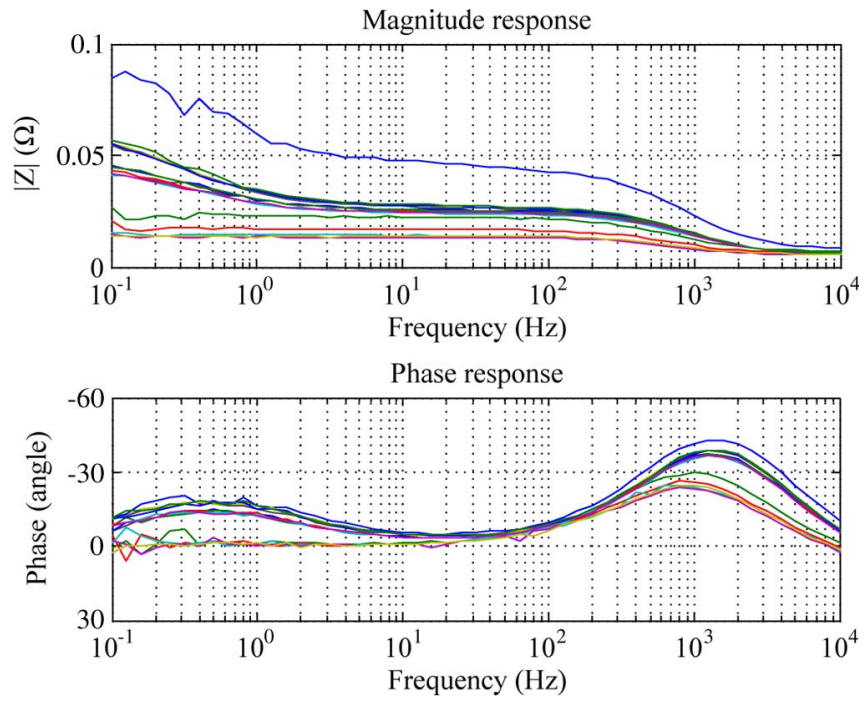

Fig. 10. Magnitude and phase responses of the cell during drying.

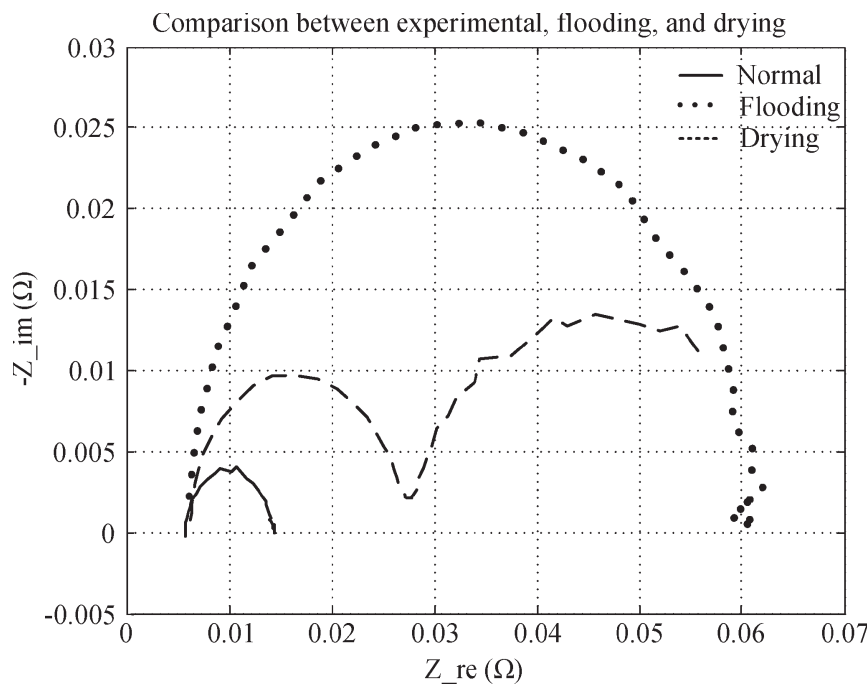

Fig. 11. Impedance response of a healthy, a flooded, and a dried cell.

be used for isolating the cause of the fault. A transient analysis on the cell voltage can also be used to isolate the faults. A combination of both isolation methods (low-frequency test and transient analysis) provides a better decision. A comparison of the normal, flooding, and drying impedance response is shown in Fig. 11. The response of the normal and flooding states contains one semicircle with the exception that a higher magnitude response occurs during flooding, whereas the response during the drying state contains two semicircles, which makes it different from the flooding fault. A simple analysis of the magnitude response at low frequency $(0.01-1 \mathrm{~Hz})$ results in an adequate signature to identify the fault type.

\section{PEMFC MOdel INCLUding FloOding AND DRYING}

A fuel cell model that contains the flooding and drying faults is developed, as shown in Fig. 12. An equivalent circuit is added to an existing PEMFC model to account for the effect of both the flooding and drying faults. For a healthy cell, the parameters $R_{1}, R_{2}$, and $C_{2}$ are considered in the PEMFC

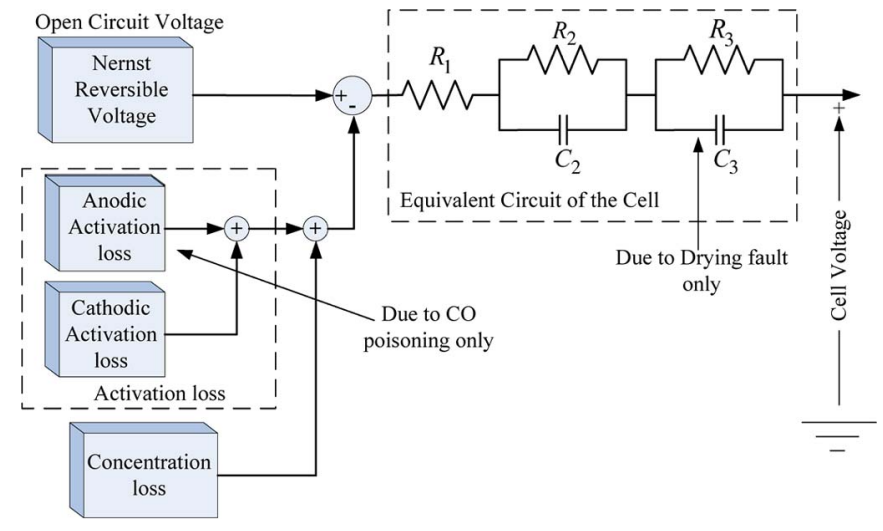

Fig. 12. PEMFC model, including flooding and drying.

TABLE I

PEMFC Equivalent Circuit Parameters of the C AND CPE Model. (a) PARAMETERs OF THE C MOdel. (b) PARAMETERS OF THE CPE MODEL

\begin{tabular}{|c|c|c|c|c|c|c|}
\hline Cell Status & $\mathrm{R}_{1}(\Omega)$ & \multicolumn{2}{|c|}{$\mathrm{R}_{2}(\Omega)$} & $\mathrm{C}_{2}(F)$ & $\mathrm{R}_{3}(\Omega)$ & $\mathrm{C}_{3}(F)$ \\
\hline \multicolumn{7}{|c|}{ Healthy Cell } \\
\hline Normal & 0.00418 & \multicolumn{2}{|c|}{0.0051} & 0.0625 & 0.0 & infinity \\
\hline \multicolumn{7}{|c|}{ Flooding Cell } \\
\hline Stage I & 0.00450 & \multicolumn{2}{|c|}{0.00662} & 0.04502 & 0.0 & infinity \\
\hline Stage II & 0.00495 & \multicolumn{2}{|c|}{0.00770} & 0.03500 & 0.0 & infinity \\
\hline Stage III & 0.00550 & \multirow{2}{*}{\multicolumn{2}{|c|}{$\begin{array}{l}0.00965 \\
0.01270\end{array}$}} & 0.03205 & 0.0 & infinity \\
\hline Stage IV & 0.00635 & & & 0.02750 & 0.0 & infinity \\
\hline \multirow[t]{2}{*}{ Flooded } & 0.01750 & \multirow{2}{*}{\multicolumn{2}{|c|}{$\begin{array}{c}0.17000 \\
\text { Drying Cell }\end{array}$}} & 0.00510 & 0.0 & infinity \\
\hline & & & & & & \\
\hline Stage I & 0.00508 & \multicolumn{2}{|c|}{ Drying Cell } & 0.03850 & 0.001400 & 600.0 \\
\hline Stage II & 0.00535 & \multicolumn{2}{|c|}{0.001550} & 0.03150 & 0.009025 & 400.0 \\
\hline Stage III & 0.00645 & \multicolumn{2}{|c|}{0.012600} & 0.02250 & 0.002900 & 300.0 \\
\hline Stage III & 0.00625 & \multicolumn{2}{|c|}{0.018300} & 0.01350 & 0.018200 & 25.54 \\
\hline Stage IV & 0.00625 & \multicolumn{2}{|c|}{0.021250} & 0.01150 & 0.028850 & 15.55 \\
\hline Dried & 0.00835 & \multicolumn{2}{|c|}{0.036900} & 0.00865 & 0.049500 & 11.55 \\
\hline \multicolumn{7}{|c|}{ (b) } \\
\hline $\begin{array}{c}\text { Cell } \\
\text { Status }\end{array}$ & $\mathrm{R}_{1}(\Omega)$ & $\mathrm{R}_{2}(\Omega)$ & $\mathrm{Q}$ & $\mathrm{R}_{3}(\Omega)$ & $\mathrm{C}_{3}(F)$ & $\mathrm{n}$ \\
\hline & & Healthy & & & & \\
\hline Normal & 0.00418 & 0.0051 & 0.1520 & 0.0 & infinity & 0.9 \\
\hline & & Flooding & & & & \\
\hline Stage I & 0.00450 & 0.00662 & 0.1012 & 0.0 & infinity & 0.90 \\
\hline Stage II & 0.00495 & 0.00770 & 0.0902 & 0.0 & infinity & $\overline{0.90}$ \\
\hline Stage III & 0.00550 & 0.00965 & 0.0705 & 0.0 & infinity & 0.90 \\
\hline Stage IV & 0.00635 & 0.01270 & 0.0575 & 0.0 & infinity & 0.90 \\
\hline Flooded & 0.01750 & 0.17000 & 0.0051 & 0.0 & infinity & 1.00 \\
\hline & & Drying & & & & \\
\hline Stage I & 0.00508 & 0.00850 & 0.05850 & 0.00140 & 600.0 & 0.93 \\
\hline Stage II & 0.00535 & 0.00155 & 0.05810 & 0.00903 & 400.0 & 0.93 \\
\hline Stage III & 0.00645 & 0.01260 & 0.03850 & 0.00290 & 300.0 & 0.93 \\
\hline Stage III & 0.00625 & 0.01830 & 0.01850 & 0.01820 & 25.54 & 0.96 \\
\hline Stage IV & 0.00625 & 0.02125 & 0.01650 & 0.02885 & 15.55 & 0.96 \\
\hline Dried & 0.00835 & 0.03690 & 0.00955 & 0.04950 & 11.55 & 0.96 \\
\hline
\end{tabular}

model to represent the cell equivalent impedance. These three parameters start to change as a result of the flooding and drying faults. The increase in the value of the first parallel $R C$ circuit $\left(C_{2}\right.$ and $R_{2}$ ) is a significant marker of flooding only. The change in these parameters is introduced as a decrease in capacitance $C_{2}$ and an increase in resistance $R_{2}$. The parameters $C_{3}$ and $R_{3}$ are not affected by flooding, but drying of the cell. The model of the drying fault considers not only the parameter changes in $C_{2}$ and $R_{2}$ but also $R_{1}$ and the addition of the second parallel $R C$ circuit $C_{3}$ and $R_{3}$, as shown in Fig. 12.

The first $R C$ parallel circuit $\left(C_{2}\right.$ and $\left.R_{2}\right)$ is replaced by a resistor $R$ in parallel to a constant-phase-element (CPE) impedance. A CPE impedance is an equivalent electrical circuit 


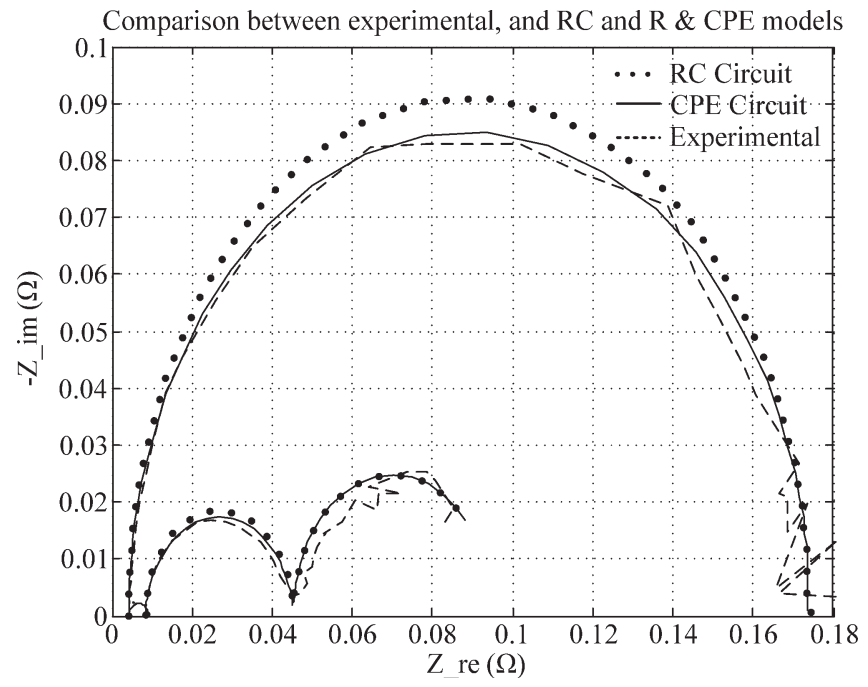

Fig. 13. Comparison between the experimental, C, and CPE model for normal, flooding, and drying.
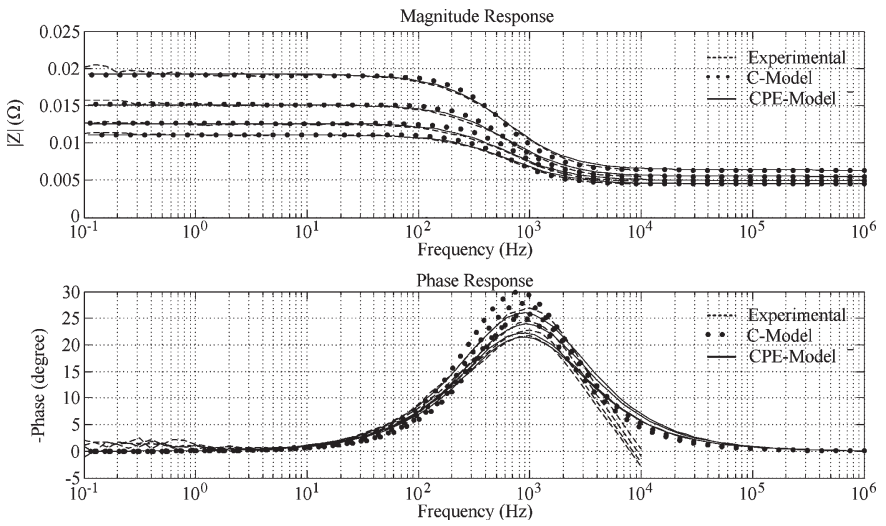

Fig. 14. Magnitude and phase responses of the experimental, C, and CPE model during flooding.

component that models the behavior of a double layer, that is an imperfect capacitor, which is given by

$$
\frac{1}{Z}=Y=Q *(j w)^{n}
$$

where $Z$ is the CPE impedance, $Y$ is the CPE admittance, $Q$ is the admittance in siemens at $w=1 \mathrm{rad} / \mathrm{s}, w$ is the frequency in radians per second, and $n$ is between zero and one. The CPE is introduced since the impedance response of the cell is not a semicircle centered at the real axis but below the real axis. However, the depressed semicircle impedance response can be approximated well by using the CPE impedance. The CPE impedance value depends on the electrode roughness, the distribution of reaction rates, varying thickness or composition of a coating, and nonuniform current distribution [10]-[12].

The CPE impedance can be approximated by a capacitive impedance for $n$ values that are very close to one. However, the true capacitance value can be expressed as [12]

$$
C=Q *\left(w_{\max }\right)^{n-1}
$$

where $w_{\max }$ is the frequency at which the imaginary component reaches the maximum, which is $w_{\max }=3958 \mathrm{rad} / \mathrm{s}$.

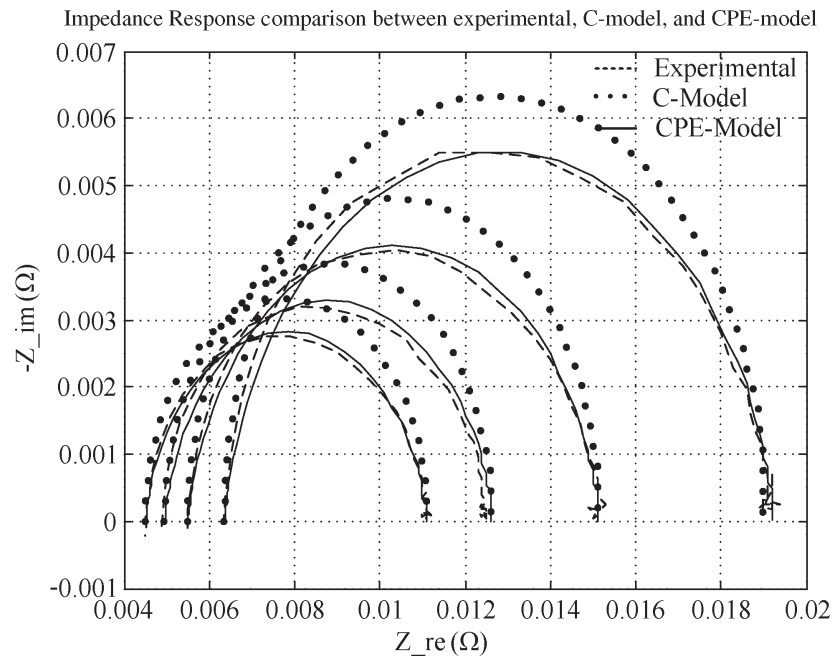

Fig. 15. Impedance response of the experimental, $\mathrm{C}$, and $\mathrm{CPE}$ model during flooding.
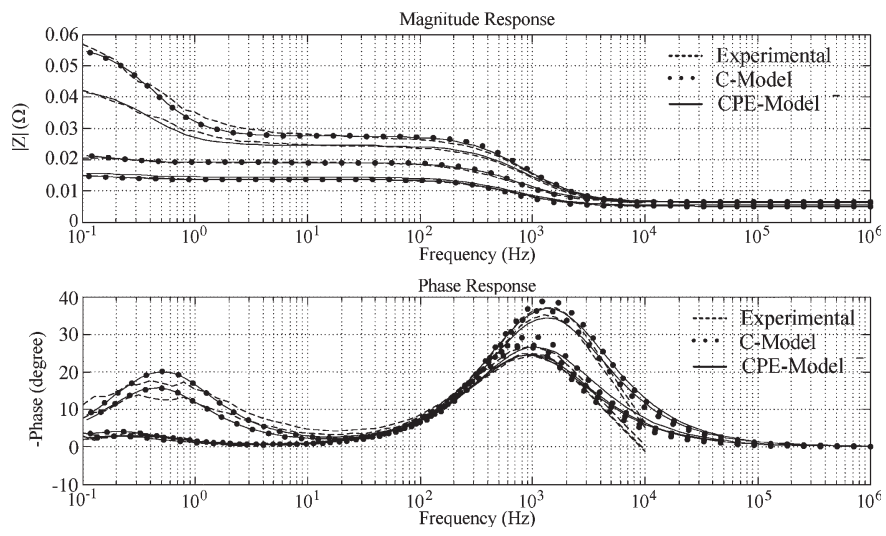

Fig. 16. Magnitude and phase responses of the experimental, C, and CPE model during drying.

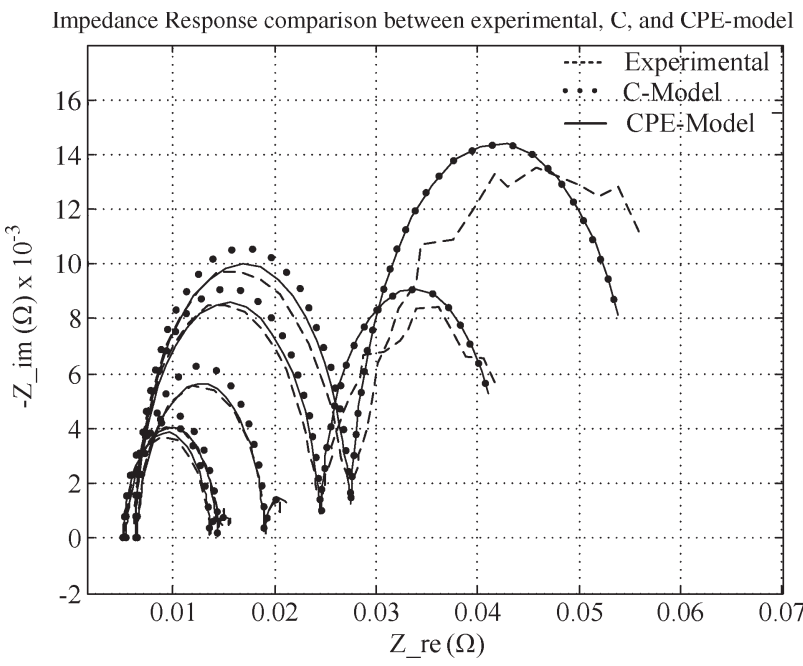

Fig. 17. Impedance response of the experimental, $\mathrm{C}$, and CPE model during drying.

The parameters of the C- and CPE-model equivalent circuit are given in Table I(a) and (b) for both faults at different level of flooding and drying.

A comparison of the impedance response between experimental, C model, and CPE model is shown in Figs. 13-17. Fig. 13 shows the plot of the impedance response for the 


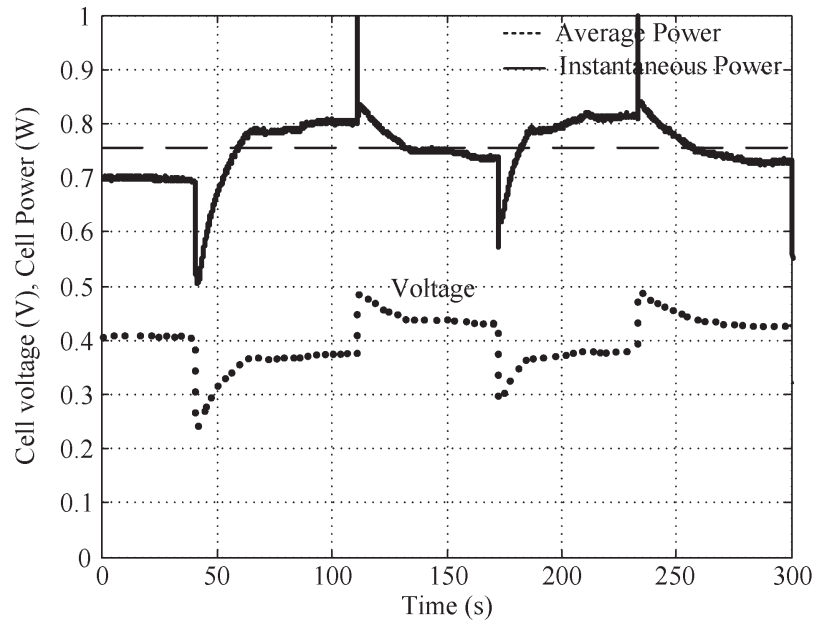

(a)

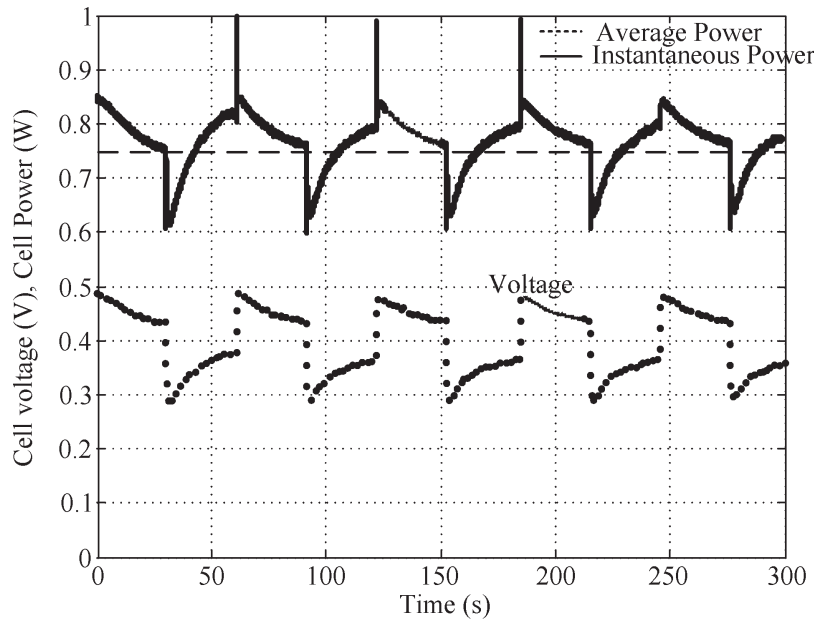

(b)

Fig. 18. Improved performance of the drying cell when pulsing the cell current. (a) Voltage and power waveforms at $T s=120 \mathrm{~s}$. (b) Voltage and power waveforms at $T s=60 \mathrm{~s}$.

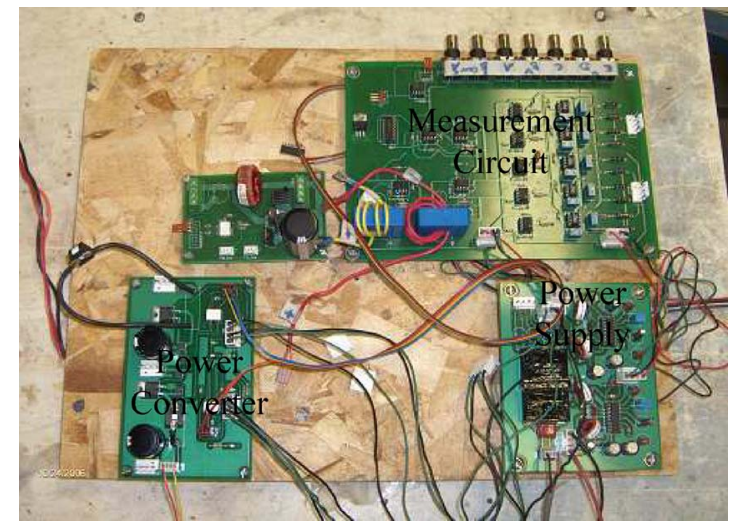

Fig. 19. Power electronic converter setup circuit.

healthy, flooded, and dried cell. Figs. 14 and 16 show the magnitude and phase responses for both models during flooding and drying, and the impedance response for both faults is shown in Figs. 15 and 17. These plots show the comparison between the experimental, $\mathrm{C}$, and CPE models at different stages of flooding and drying. It can be observed that the CPE model responds better in both fault modeling cases. However, the

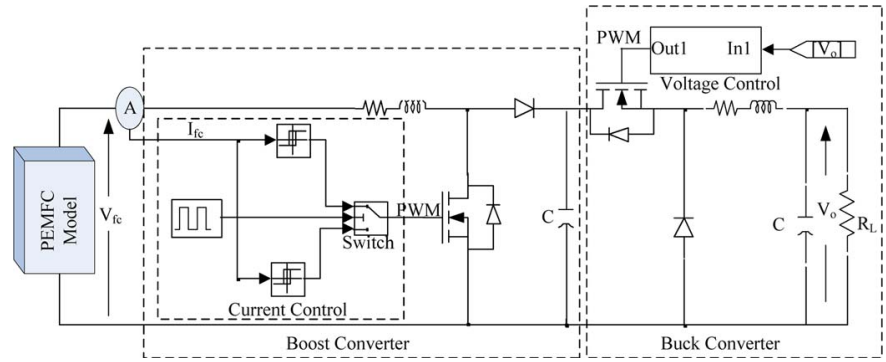

Fig. 20. Fuel cell interconnected to the power converter simulation circuit.

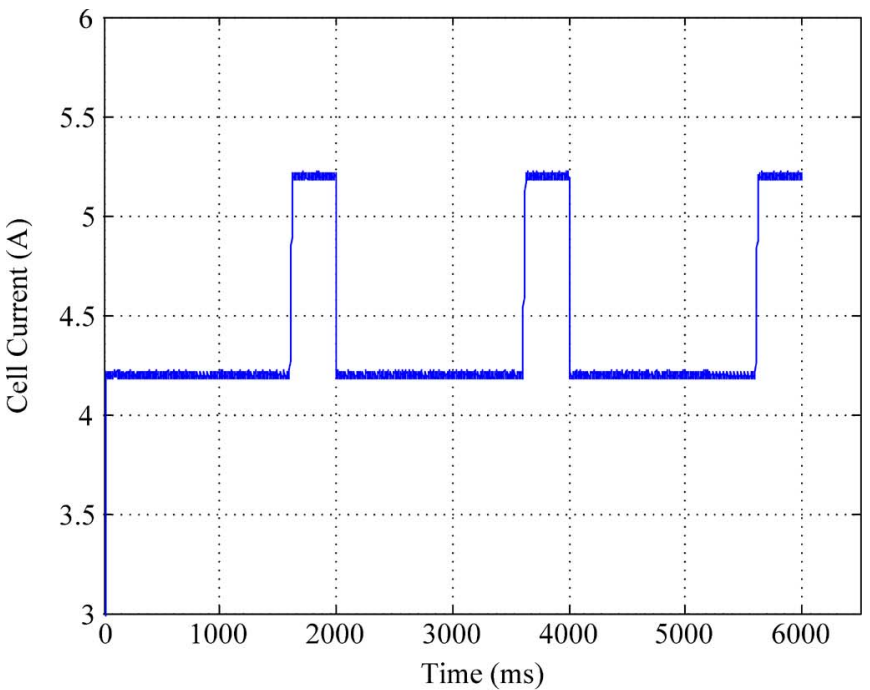

(a)

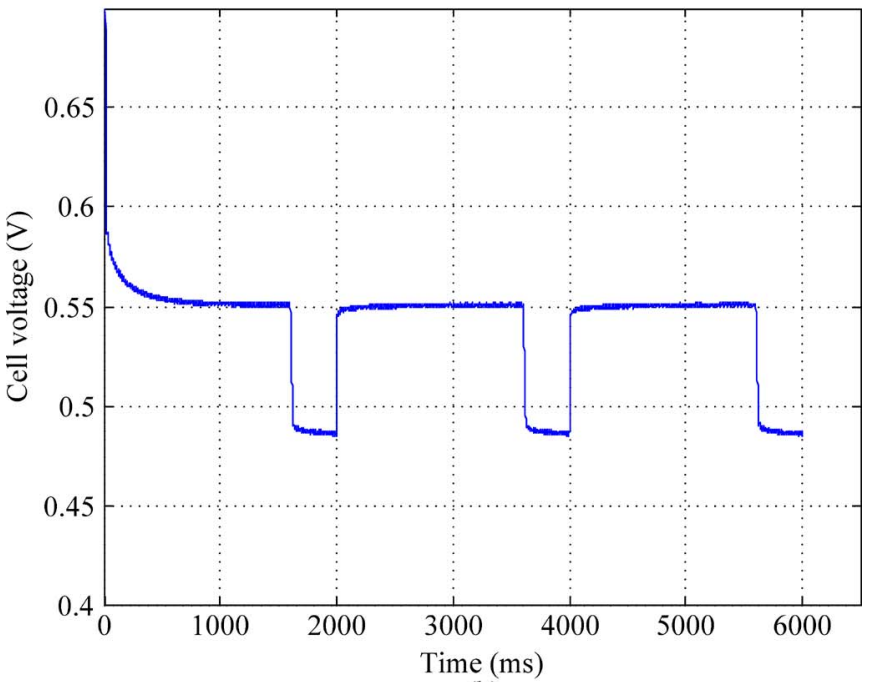

(b)

Fig. 21. Cell current and cell voltage waveforms of a PEMFC. (a) Pulsing cell current waveform. (b) Voltage response of the cell.

$\mathrm{C}$ model has the advantage of simple circuit implementation in MATLAB/Simulink or PSpice as a tradeoff to a better approximation.

\section{Proposed Method of Improving PeMFC Performance Using Power Converter}

The PEMFC problems discussed in the previous sections can be mitigated by selecting the best suitable operating point in the $V-I$ curve of the fuel cell. For example, a low-current operation 


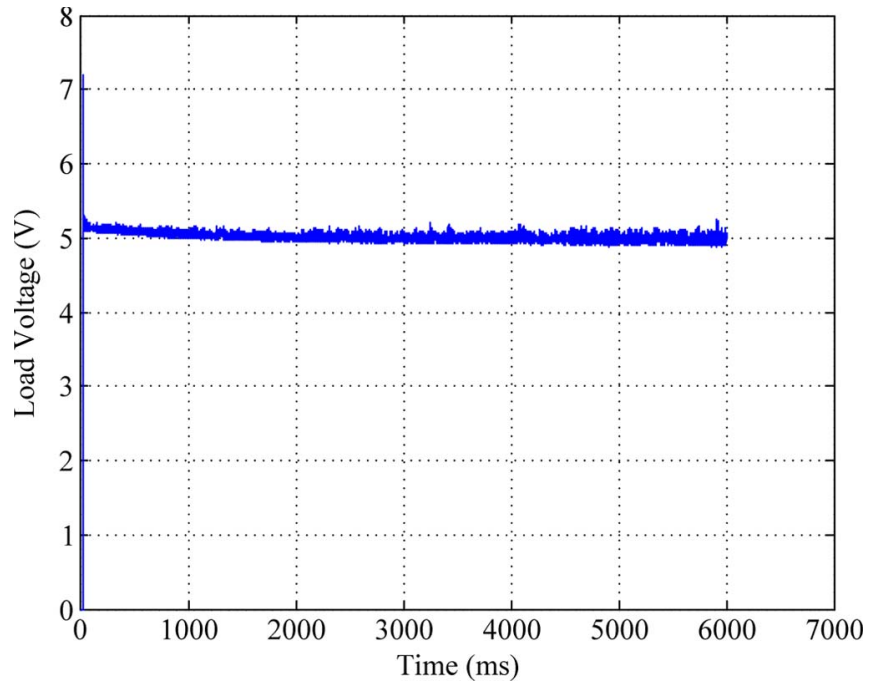

Fig. 22. Voltage waveform of the buck converter load.

has the advantage of mitigating the flooding fault, which is observed during the experiment. The drying and $\mathrm{CO}$ poisoning faults of the PEMFC are mitigated by operating at high current densities. A high-current-density operation results in more water production at the cathode side, which increases the liquid water in the membrane. During the drying experimental test, it was observed that the performance of the cell was improved by pulsing the cell current between 8 and $10 \mathrm{~A}$, as shown in Fig. 18. Arbitrary switching periods $(T s) 1$ and 2 min of $50 \%$ pulsewidth increased the average cell power by $8 \%$. This operating point is also favorable for the $\mathrm{CO}$ at the anode side to be oxidized and allow additional surface area in the Pt catalyst for the incoming hydrogen (fuel). Overall, the performance of the PEMFC is improved by employing a power converter that controls the fuel cell operation during these faults.

Fig. 19 shows the power converter connected at the terminals of the PEMFC. The power converter is made of a boost-cascade-buck converter. The boost converter controls the voltage and current operating point of the cell, while the buck converter provides constant output power (voltage) to the load.

The power converter connected to the terminals of a PEMFC is simulated in a MATLAB/Simulink program. A current control is implemented using two hysteresis current control loops and a switch, as shown in Fig. 20. The hysteresis loops control the magnitude of the cell current, whereas the switch controls the switching frequency and the pulsewidth between the two current magnitudes of the cell. A PI controller of the buck converter ensures a constant voltage output to the load.

The cell current, the cell voltage, and the load voltage of the simulation are shown in Figs. 21 and 22. Fig. 21(a) and (b) shows the pulsing current drawn and the voltage waveforms of the cell. The cell current is controlled at 4.25 and $5.25 \mathrm{~A}$ by the hysteresis controls, and the corresponding cell voltages are 0.55 and $0.475 \mathrm{~V}$. The load voltage at the terminals of the buck converter is controlled at $5 \mathrm{~V}$, as shown in Fig. 22. Experimental tests of the power converter shown in Fig. 22 were done to show proper operation. The power converter is connected to a dc power source instead of the actual PEMFC. The pulsing current drawn by the power converter is shown in

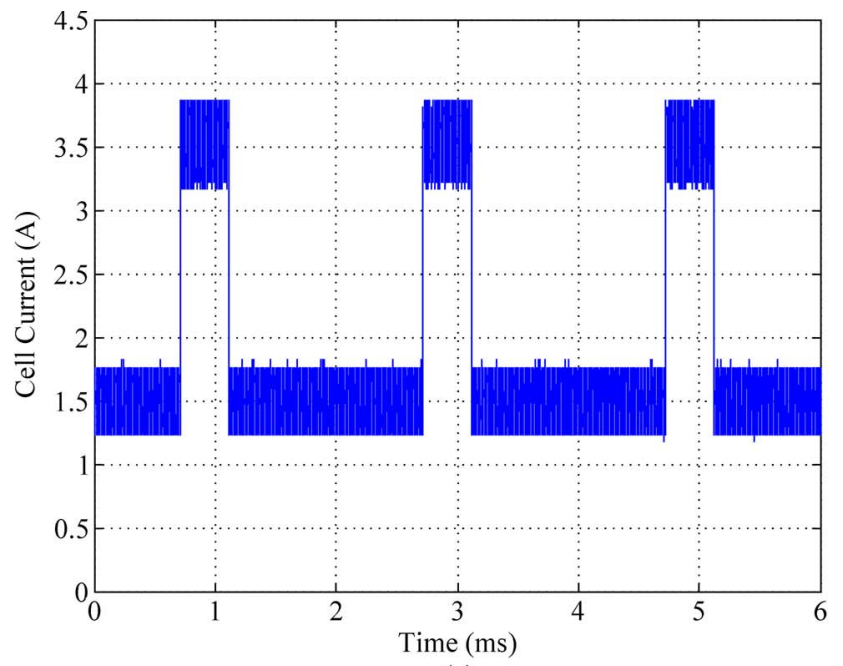

(a)

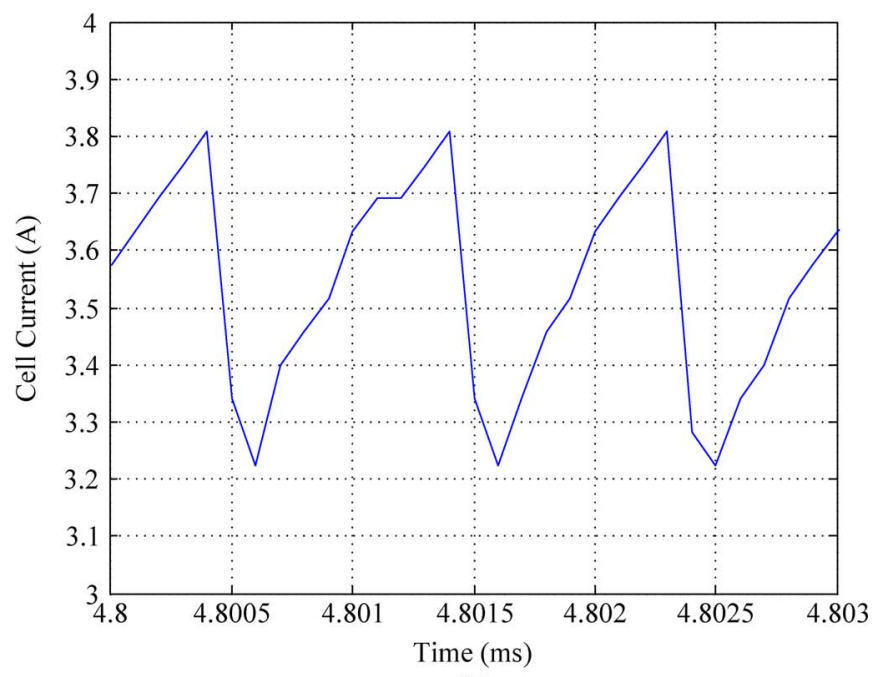

(b)

Fig. 23. Pulsing current waveform of the power converter experimental test. (a) Current waveform of the boost converter. (b) Ripple current of the boost converter.

Fig. 23. The source current is controlled at an average of 1.5 and 3.5 A, as shown in Fig. 23(a). A maximum current ripple of $\Delta i=0.5 \mathrm{~A}$ occurs when the average current is $3.5 \mathrm{~A}$, as shown in Fig. 23(b). The reason for the high current ripple is due to the delay in the reading sensors, the limitation of the controller, and the inductor size. The ripple can significantly be reduced either by increasing the inductor size or increasing the switching frequency of the boost converter. As a result of these changes, the efficiency of the power converter will decrease.

\section{CONCLUSION}

In this paper, an experimental setup of a single-cell PEMFC for flooding and drying tests was presented. The impedance response due to the flooding and drying faults was briefly discussed. The impedance response at low frequency was found to carry the information required for isolating the cause of the fault. A pure capacitance and a CPE-based model were discussed to represent the equivalent circuit of the cell impedance. The CPE-model equivalent circuit showed better approximation 
of the cell impedance as compared to the $\mathrm{C}$ model. However, the $\mathrm{C}$ model is simple and well known in simulation.

A power converter circuit was built to mitigate the faulty cell. Pulsing the cell current at low frequency (about $0.0085 \mathrm{~Hz}$ ) improves the performance of the cell. The cell voltage was seen to increase due to the pulsing and higher water production at higher cell current. Simulation and experimental results of the converter were presented to show proper operation. The converter controls the cell current and voltage operating points, which mitigates the fault.

\section{REFERENCES}

[1] A. Rodrigues, J. C. Amphlett, R. F. Mann, B. A. Peppley, and P. R. Roberge, "Carbon monoxide poisoning of proton-exchange membrane fuel cells," in Proc. 32nd IECEC, Jul. 27-Aug. 1, 1997, vol. 2, pp. 768-773.

[2] Z. Qi and A. Kaufman, "CO-tolerance of low loaded Pt/Ru anodes for fuel cells," J. Power Source, vol. 113, no. 1, pp. 115-123, 2003.

[3] S. Gottesfeld and J. Pafford, "A new approach to the problem of carbon monoxide poisoning in fuel cells operating at low temperature," J. Electrochem. Soc., vol. 135, p. 2561, 1988.

[4] F. A. Uribe, T. A. Zawodzinki, J. A. Valerio, and F. H. Garzon, "PEMFC reconfigured anodes for enhancing CO tolerance with air bleed," J. Electrochem. Soc., vol. 7, no. 10, pp. A376-A379, 2004.

[5] M. Murthy, M. Esayian, W.-K. Lee, and J. W. Van Zee, "The effect of temperature and pressure on the performance of PEMFC exposed to transient CO concentrations," J. Electrochem. Soc., vol. 150, no. 1, pp. A24-A34, Jan. 2003.

[6] W. Choi, P. N. Enjeti, and A. J. Appleby, "An advanced power converter topology to significantly improve the CO tolerance of the PEM fuel cell power systems," in Conf. Rec. IEEE IAS Annu. Meeting, 2004, pp. 1185-1191.

[7] W. He, G. Lin, and T. V. Nguyen, "Diagnostic tool to detect electrode flooding in proton exchange membrane fuel cells," AIChE J., vol. 49, no. 12, pp. 3221-3228, 2003.

[8] F. Barbir, H. Gorgun, and X. Wang, "Relationship between pressure drop and cell resistance as a diagnostic tool for PEM fuel cells," J. Power Sources, vol. 141, no. 1, pp. 96-101, Feb. 2005.

[9] W. McYerida, D. A. Harrington, J. M. Le Canut, and G. McLeand, "Characterisation of proton exchange membrane fuel cell (PEMFC) failures via electrochemical impedance spectroscopy," J. Power Sources, vol. 161, no. 1, pp. 264-274, Oct. 2006.

[10] N. Fouquet, C. Doulet, C. Nouillant, G. Dauphin-Tanguy, and B. OuldBouamamab, "Model based PEM fuel cell state-of-health monitoring via ac impedance measurements," J. Power Sources, vol. 159, no. 2, pp. 905913, Sep. 2006.

[11] D. J. Hall and R. G. Colclaser, "Transient modeling and simulation of a tubular solid oxide fuel cell," IEEE Trans. Energy Convers., vol. 14, no. 3, pp. 749-753, Sep. 1999.

[12] W. H. Mulder, J. H. Sluyters, T. Pajkossy, and I. Nyikos, "Tafel current at fractal electrodes. Connection with admittance spectra," J. Electroanal. Chem., vol. 285, no. 1/2, pp. 103-115, 1990.

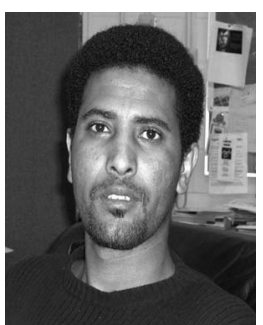

Abraham Gebregergis (S'07-M'08) received the B.S. degree from Asmara University, Asmara, Eritrea, in 2001, the M.S. degree from Stellenbosch University, Stellenbosch, South Africa, in 2004, and the Ph.D. degree from Clarkson University, Potsdam, NY.

He is currently with Delphi Steering Saginaw, Saginaw, MI, as a Project Engineer. His research interests include power electronics, drives and machines, electric power steering, control, and fuel cell modeling.

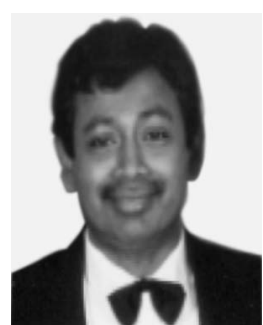

Pragasen Pillay (S'84-M'87-SM'92-F'05) received the B.S. and M.S. degrees from the University of KwaZulu-Natal, Durban, South Africa, in 1981 and 1983, respectively, and the Ph.D. degree from Virginia Polytechnic Institute and State University, Blacksburg, in 1987, while funded by a Fulbright Scholarship.

From January 1988 to August 1990, he was with the University of Newcastle upon Tyne, Newcastle upon Tyne, U.K. From August 1990 to August 1995, he was with the University of New Orleans, New Orleans, LA. From 1996 to December 2007, he was with Clarkson University, Potsdam, NY. He is currently with Concordia University, Montreal, QC, Canada, where he is a Professor and Hydro-Quebec Senior Chair in the Department of Electrical and Computer Engineering and holds the Jean Newell Distinguished Professorship in Engineering. He has also been an Adjunct Professor at the University of Cape Town, Cape Town, South Africa, since 1999. His research and teaching interests are in modeling, design, and control of electric motors and drives for industrial and alternate energy applications.

Dr. Pillay is a Fellow of the Institution of Engineering and Technology, U.K., and a Chartered Electrical Engineer. He is a member of the Academy of Science of South Africa, the IEEE Power Engineering, IEEE Industry Applications, IEEE Industrial Electronics, and IEEE Power Electronics Societies. He is also a member of the IEEE Industry Applications Society (IAS) Electric Machines Committee, the Past Chairman of the IEEE IAS Industrial Drives Committee, and the past Chairman of the IEEE Power Engineering Society Induction Machinery Subcommittee. He has organized and taught short courses on electric drives at the Annual Meeting of the IEEE Industry Applications Society. He is currently the Chair of the Awards Committee of the IEEE IAS Industrial Power Conversion Department.

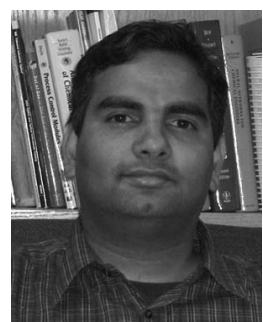

Raghunathan Rengaswamy received the B.S. degree from the Indian Institute of Technology (IIT), Chennai, India, in 1990, and the Ph.D. degree from Purdue University, West Lafayette, IN, in 1995.

From 1996 to 2000, he was with IIT, Mumbai, India. He was a Visiting Professor at the University of Delaware, Newark, in summer 1999, at Purdue University in winter 2001 , and at the University of Alberta, Edmonton, AB, Canada, in summer 2002. He was with the Department of Chemical and Biomolecular Engineering, Clarkson University, Potsdam, NY, where he was an Associate Professor from January 2002 to June 2008 and a Professor from July to December 2008. He is currently a Professor in the Department of Chemical Engineering, Texas Tech University, Lubbock. His research and teaching interests are in modeling, optimization, diagnostics, and control of proton exchange membrane and solid oxide fuel cells, chemical process calculations, mathematical methods, computer-aided design, advanced process control, and AI techniques in process engineering.

Dr. Rengaswamy was the recipient of the Young Engineer Award in 2000 awarded by the Indian National Academy of Engineering. He was chosen by the students of chemical engineering at Clarkson University as the Professor of the Year in 2003 . 